\title{
Disappearing Socialism: Volker Braun's Unvollendete Geschichte
}

(Published in Monatshefte, 102.2, 2010)

Socialism has begun to disappear. ${ }^{1}$ There is abundant evidence for this development. One can cite symbolic acts such as the dismantling of socialist monuments in Eastern Europe or the renaming of cities bearing the name of communist leaders and theorists, ${ }^{2}$ or socio-economic shifts such as the embrace of neo-liberal policies in former socialist countries in the Eastern bloc or the rise of China as a major economic power on a global market. Or one can look at the accumulating reports about the withering consciousness of past political repression: young people living in the Eastern part of contemporary Germany, perhaps brought up in an era of "Ostalgie," possess little knowledge of dictatorial practices in the GDR. ${ }^{3}$ These symptoms may seem to contradict each other, but in fact represent convergent tendencies: socialism as it was once practiced in the "Second World" - its repertoire of symbols, its distinct way of organizing the economy, its methods of censorship and coercion - has not been completely erased, but appears to be sliding from collective memory. ${ }^{4}$

In this article, I will focus on a particularly vulnerable aspect of socialism's legacy, namely the socialist arguments against the once prevailing socialist regimes in Eastern Europe. While we may retain a sense of socialism's own rhetoric, and also remember quite clearly, or perhaps still espouse, the major arguments against socialism developed in the West during the Cold War, ${ }^{5}$ the ideologically and politically socialist 
critique of socialist countries is now almost concealed. We know that basic freedoms were routinely denied to the citizens of socialist nations and we can trace the stagnation and decline of the socialist political and economic systems according to criteria of democratic legitimacy, transparency, productivity and efficiency. ${ }^{6}$ It is much harder, however, to retrieve and fully articulate arguments against this socialist system that are based entirely on socialist premises. After all, this system suffered a breakdown, and as a consequence, the critical arguments generated within the framework of its guiding philosophy have also been swept away.

To demonstrate this, I would like to turn to the work of Volker Braun, an East German author critical of the GDR regime, and therefore censored by it, but known for stubbornly sticking to socialist ideals. I will concentrate on a novella entitled Unvollendete Geschichte from 1977, which I believe illuminates the curious phenomenon of disappearing socialism in an exemplary fashion. ${ }^{7}$ Given the uncompromising critique this novella levels against the East German state, it is difficult today to see how it can be regarded as a socialist piece of literature. Yet Braun's overarching purpose in this text is to mobilize theoretical resources within the socialist tradition. My aim is to recover this lost horizon within a single work, and by completing this interpretive task attempt to expand, however minimally, today's determining modes of thought.

\section{I.}

Volker Braun's novella Unvollendete Geschichte from 1977 leveled a critique at East Germany. Or rather, it did not level a critique so much as it confirmed a critical argument which had then already been established and which has now solidified into an 
undeniable truth. This argument can be summarized in the following way: the GDR was a country run by an authoritarian regime which severely limited the opportunities for individuals to pursue their own ambitions and live as they desired, and which reacted with cruelty and pedantic possessiveness when faced with even the vaguest and most allusive hints of dissent.

A minimal plot summary brings out how Braun's story offers a captivating but at the same time utterly unsurprising case study in the mechanisms of socialist oppression. At the beginning of the novella, the eighteen-year old Karin is about to begin work as an intern at a newspaper in an unidentified East German town. This employment represents a first step in a long vetting process, in which her loyalty and aptitude will be tested for an eventual position of responsibility. The conditions at the start could not be more auspicious. Karin's father is a local government official of some prominence, her mother is a journalist, and she has herself already amassed a good record throughout her years in school. As she embarks on her training at the editorial office, she is united with those who supervise her preparation in a relationship of mutual trust: she has faith in the will of all to advance socialism, and while they do not absolve her from routine scrutiny, they encourage her and recognize her diligence. Braun describes the continually managed and reinforced fit between the young subject and the authority figures - parental, professional, and party-based - that occupy the interlinked stations of a single path. At the outset, Unvollendete Geschichte seems to provide, in the form of a story, an almost sociological assessment of the socialist elite's ability to regenerate itself.

Karin's journalist training is immediately disturbed and eventually derailed, however, when she refuses to leave a young man with a troubled past. She is in love with 
Frank, who once belonged to a gang of delinquents and is now suspected of entertaining contacts with illegal defectors. Karin's parents, the managers at her new workplace, as well as party representatives who oversee her case, all urge her to leave Frank so as not to jeopardize her future prospects or damage her father's reputation. As she first complies and announces the break-up to Frank, he slips into despair and tries to commit suicide, sustaining serious injuries. Shocked, remorseful and increasingly sure of the intensity of her feelings, Karin soon goes against the wishes of her elders - the conglomerate of parents, superiors, and party officials - and re-unites with the convalescing Frank. But her obstinacy is costly; she is dismissed from her job and estranged from her family.

The oppositions set up in Braun's novella, between the young couple and the disapproving establishment, or between the fulfillment of individual happiness and the constricting demands for loyalty, suggest a society unable to accommodate the desire of the young to love who they happen to love and fashion their own lives. ${ }^{8}$ In a straightforward way, Unvollendete Geschichte depicts an all-too easily activated familyparty-state unit ready to intervene against and penalize unwanted contacts on questionable grounds. The asymmetry of the conflict between the apparatus and the single subject is further dramatized by the use of a stylistic device that indicates the weight of the prevailing powers, or the scope of their hegemony. In the novella's lengthy sections of erlebte Rede, Braun shows how Karin's thoughts continue to cluster around socialist key words and phrases - capitalized in the text so as to be easily identifiable that connect into chains of evaluative storytelling. ${ }^{9}$ The reader is made aware of the moments in which her ruminations rely upon shared idioms, as if her consciousness was a conduit for an impersonal and constraining phraseology: 
Und sie [Karin] war doch auf ihre Eltern stolz, wenn sie sie mit den anderen verglich. Zum Beispiel mit Franks Eltern. Weil sie jede Möglichkeit wahrgenommen hatten, die Gesellschaft mit aufzubaun. [. . .] Das war schwer gewesen. Es war alles langsam gegangen, jeder Erfolg mühsam ORGANISIERT. [. . . ] Sie hatten sich in die Arbeit gestürzt, DIE JA SONST KEINER MACHT. Und sich selbst getrieben, bis sie nichts andres mehr konnten. Sie dachten nur noch POLITISCH. ANDERE LEUTE dachten nur an sich. Die ließ dieses ganze Kämpfen kalt. Das stieß die ab. Die ZOGEN SICH ZURÜCK. Die zogen ihr blödes PRIVATLEBEN vor. (81)

The message of Unvollendete Geschichte could hardly be more obvious: Karin is not allowed to make her own choices; she is, in fact, barely able to speak in her own words. East Germany declares its demands through a megaphone right into her mind, and when she persists in her behavior, it discharges her from her job, her social surroundings, and even her family. Indeed, our familiarity with the lines of conflict drawn up in Unvollendete Geschichte, the ease with which the story lets itself be schematized into polarities such as young versus old, individual versus apparatus, almost seems to cancel out the need for further scrutiny. The target of critique is made recognizable down to the level of the sentence, where typographical manipulations highlight the presence of an oppressive ideology in the fabric of every thought.

And yet Volker Braun himself was and is a socialist, famously unwilling to retire any of his convictions. In an essay on the novella from 1996 entitled "Das Ende der Unvollendeten Geschichte," Braun himself lists approving statements from a host of West German reviews, all of which corroborate each other. His novella, these reviewers claim, document "die Praktiken des 'Ministeriums für Staatssicherheit"”; the two young lovers are persecuted by "eine dumme, hochmütige, inhumane Staatsräson" etc. ${ }^{10}$ While Braun does not spell out his resistance to these characterizations, his act of collecting them betrays his discomfort at the repeated judgment of his text. Braun appears to be at 
odds with the critics, whose appreciative reviews of his image of East Germany seem only to summarize and underline what the story already makes quite clear. If the work was once written with a socialist agenda, this has been quickly and easily obscured, and not even Braun himself seems willing or able to reconstruct his original point of view. Socialism left no perceptible trace..$^{11}$

The question for us, then, is this: can this socialism be rendered legible again, despite Braun's own difficulties? It is true that the main character Karin falls out of favor and is nearly ostracized, but she quickly turns her experience of isolation into a source of knowledge, specifically a source of knowledge of the state and its language. This knowledge of the state and its language is, further, knowledge of denied or disavowed social interconnection and interdependence. It is, finally, on the basis of this knowledge of the state as a frozen, institutionalized denial of social interconnection that the GDR can be criticized from within the socialist tradition, as Braun conceives of it. To recover the socialism of Unvollendete Geschichte, we must see how this novella regrets rather than celebrates the divisions between individual and state that it nonetheless faithfully observes.

\section{II.}

How does the novella let its protagonist arrive at an understanding of the state informed by socialist notions of human interdependence and ideals of collectivism? When Karin confronts the warnings about her boyfriend, channeled to her through a succession of authority figures, she is caught between "divergent allegiances." ${ }^{12}$ She is completely loyal to her parents and their sense of vocation in the GDR while at the same 
time perplexed by and incredulous at the suspicions of Frank. This failure to align her judgment with the prevailing judgment of her environment does not only bring with it the frustration of a stalling education or career. Rather, Karin finds herself in discord with the world of which she is part, or with the world that she is. She is hurled out of the system of agreements about how people and events should be evaluated, or even what things should be called. The rupture is simultaneously social and perceptual, for her confident cognitive grasp of her surroundings is indissolubly linked to her security in a social world that embeds her in supportive familial and collegial relationships. Her attunement to reality depends on the steady certification she draws from attitudes and orientations she shares with others. When this shared orientation can no longer be taken for granted, the result is a sense of alienation: "Es war ihr für Augenblicke, als wär sie an einen fremden Ort versetzt, wo alle Gegenstände anders heißen” (10). As Karin is stripped of her comfort in the social grid, the world is stripped of its customary names. She is torn from her place in the universe of dependable axioms and pushed out into an unknown space where no labels are securely fastened to things and events.

But Karin does not simply lose the soothing obviousness of a known and stable world, or lose the "Übereinstimmung mit allem" (51). This world, or rather the maxims and idioms that describe it and indeed hold it in place, suddenly shuts her out. Despite her record of impeccable behavior, she becomes the object of unrelenting blame. Particular individuals may voice the accusations, but his or her words are inflated in the text, as if resonating with a general disapproval: "Der Vater habe ETWAS ANDERES von ihr erwartet. Die Mutter sei bekümmert. Dieses Zusammenziehn sei unsittlich, Karin sei ABGEGLITTEN. Der Ausdruck ASOZIAL war vorgekommen" (31). These parental 
admonitions, in which an entire social environment finds utterance, seem almost superfluous, however, for Karin knows the communal patters of reasoning well. Her thinking is already stamped and organized by the value-laden formulaic expressions turned against her as she falls out of the community of "GESUNDE[R] MENSCHENVERSTAND” (65). The unified language of Karin's environment - the blend of party slogans, traditional proverbs, and common euphemisms - reveals itself as the possession of the authorities. The entity that then speaks through her parents, and that also speaks in her, is, as we shall see, the state.

The way the fronts harden between Karin and the authorities does mark the failure of the GDR; there is nothing in the novella to suggest otherwise. But this does not mean that the novella does not endorse socialism. Karin herself, for instance, shows no real interest in her cause as an individual whose liberty and privacy must be protected from outside interventions. In a certain sense, she does not demand a greater space of freedom, nor does she seek to shake off the language that speaks in her mind, at least not if the alternative is conceived of as autonomous thought embodied in some new personal idiom. Braun's novella goes in the opposite direction: it stubbornly tries to re-inscribe the individual subject into the social whole that is so quick to expel her. And on the level of linguistic critique, its ongoing exposure of the "verstaatete Sprache" that occupies Karin's mind does not imply a simple polarity between the formulaic speech of socialism and the project of a more authentic, because more idiosyncratic, style. ${ }^{13}$

Of course, Karin is painfully aware that she has come to occupy the position of a stigmatized and excluded figure, but she quite clearly refuses a romantic understanding of her predicament, according to which she would be an outsider. In a book she reads a 
formulation that may seem to encapsulate her situation - "Die Harmonie zerbrach, und draußen war Kälte," - but she brushes it off as kitsch (72). In her moments of more sustained reflection, moreover, she is loath to accept the oversimplified scheme of individual versus the majority, the regime, or the state. This diagram of conflict holds no appeal to her and even seems intellectually untenable. If a rift has opened up, she finds, this rift simultaneously runs through the entire system and the individual without putting them at a remove from one another. What happens to her as a single person is of little consequence, since the actual opposition in which she is implicated is located in the collective as a whole, a fact that a facile distribution of antagonistic positions can only serve to obscure: “das bewies ja nichts, ihr 'Konflikt mit der Gesellschaft.' Sondern was dahinter war, was geschah denn da? In der Gesellschaft?" (75). Cast out, she claims a place at the very center of collective life. In Unvollendete Geschichte, the problem is not that the regime violates an individual's integrity but that it suppresses a conflict internal to the collective.

This reluctance to accept the role of the rebel in the periphery does not betray Karin's lack of confidence or her desire for renewed membership. It reflects not her weakness, but indeed her strength, since it signals her refusal to let those who have dismissed her - supervisors, party officials, and parents - define the boundaries of the world they have in common. If anything, the process of disintegration she experiences powerfully brings home the fact of her social constitution. In her most feverish and disorienting moments, she understands, in a deep, corporeal way, to what extent she depends on the agreement or the "Übereinstimmung" of others to make sense of the world, as they in turn depend on her and everyone else: the world is always explored, 
named and comprehended in a collective. The people around her who merely dispense advice and issue commands, do not have visceral contact with the truth of their inseparability from others, for their routine guardianship of specific rules bars them from the disturbing affective experience of ruptured cohesion. ${ }^{14}$ In fact, Karin's experience of destabilized interconnection with others, which only serves to highlight the fundamental significance of such interconnection, can be converted into critical knowledge of the state within the frame of the socialist tradition.

In her isolation, the protagonist of Unvollendete Geschichte comes to realize the inherently collective nature of societal life and of linguistic designation. This inchoate collectivist thinking further leads her to question the idea that there can be a locus of unapproachable authority in society, for such an authority necessarily depends upon the acceptance, implicit endorsement or at the very least the apathy of all those over whom it ostensibly presides. Toward the end of the novella, Braun inserts a key statement from Georg Büchner's pamphlet Der Hessischer Landbote into his text: “"Was ist denn nun das für ein gewaltiges Ding: der Staat?"' (78). ${ }^{15}$ This open call for an interrogation of the state encapsulates the novella's position, according to which the appearance of an authority wholly external to the community it governs is a regrettable distortion. As the radical author Büchner lays out in his manifesto, the imposing state is nothing but the active association of every inhabitant, or the concentration of their ability to cooperate with one another, even though those in (temporary) control of its apparatus strive to present it as an independent and superior entity. The people faced with the state should thus strive to reassert their agency and cast off the notion of a sharply separate government wielding some miraculous, God-given power; the strength and the resources 
of the state ultimately depends on the strength and the resources of the people who actually sustain it. ${ }^{16}$ The state in fact represents the collective agency of the people, its capacity to act in and shape the world through collaboration, but it does so in a distorted form, seemingly detached from the people and hovering above them as a self-sufficient entity.

With this critique of the mystery and opacity of the state as an external entity, Unvollendete Geschichte does not simply encourage resistance to the authorities, if this would entail pushing back some force that would be divorced from those who suffer under it. This would be the classically liberal approach to the state: liberals reject infringements by the state but thereby also preserve the notion of the state as a foreign entity. In contrast, the socialist response to the state must emerge from a widely shared recognition of the ensemble of human relationships that make up the entirety of society and without which there could not be a state in the first place. The authoritarian exercise of power involves a denial of the agreements and social relations among people upon which any course of action by the state ultimately relies. Put more simply, Karin feels that her voice should count, not because she is an inviolable individual, but because she, together with everyone else, constitutes the collective. ${ }^{17}$

In Unvollendete Geschichte, Karin's turbulent experience of isolation paradoxically reveals to her the fact of everyone's necessary interconnection. She realizes and deeply feels how the world in which she lives is socially constituted or possesses the character of a thick web of innumerable implied agreements. This dramatized fact of interconnection further discloses to her, at least in flashes, the deceptiveness of a state that appears as a fully independent and external agent or an immobile fact of life, lacking 
the transparency of a malleable and developing arrangement of and for the collective. The ideological ideal of the novella is therefore not the fortified individual able to exercise control over his or her private domain (thanks to a minimized and strictly controlled government). It is rather the fluidly cooperative collective that rediscovers its collaborative activity after a period of self-forgetting, during which agency was given over to the state.

\section{III.}

The confrontation with the state set up in Unvollendete Geschichte occurs at the level of the novella's textuality: the critique of the state is carried out through a critique of the fixed and endlessly circulating phrase. As noted above, the state inhabits the mind and the life of the protagonist in and through language. Party slogans such as "ALLES ZUM WOHL DES MENSCHEN," or proverbs with a distinctly authoritarian message, crowd in upon Karin and dominate her thinking process (40). The phrases that stiffly organize all discourse moreover seem designed to contain contestation. Their concise and idiomatic character function as a kind of protective coating; by being easily memorized to begin with and also constantly repeated, they appear to have acquired the ring of the selfevident. Speaking from within these strips of words is a peremptory "das ist so," to cite Karin's portrayal of her mother's self-assured delivery of lines such as "Der Sozialismus ist eine WISSENSCHAFT" (43). Every phrase strikes the listeners with the force of a final judgment to preemptively cancel out any future modification. ${ }^{18}$

Yet if state hegemony extends and preserves itself through language, or if the regime maintains its rule by making its repertoire of phrases the only spoken and written 
language in the nation, the rediscovery of collective agency that Braun envisions must occur in the medium of language, too. Insofar as the state protects its domination by means of phrase-making and thus possesses something of a "logocratic" character, the emancipation from this state, or the attempt to dislodge the occupants of authority from their falsely elevated position, should be accompanied by the release of speech from monopolized regulation. ${ }^{19}$ And this is precisely what happens in Unvollendete Geschichte. But it only happens in a dream.

In one of Karin's dream sequences toward the end of the novella, her parents, editors, and supervisors at the newspaper have to answer for what they have done before a gathering of workers. Led by a female textile worker, the crowd of people first move through a portal in a building that looks like a newspaper office, until they reach a big machine shop where all the authority figures that have watched over Karin are more or less harshly judged. This sequence of images constitutes a spectacle of wish fulfillment, but it also conveys the idea of workers reasserting their control over and against a minority of officials. More specifically, it depicts members of the working class breaking into the newspaper offices to recover the production and mass distribution of the word. The rebellion against the representatives of the state, which is the manifestation of a general and hence explosive rediscovery of collective agency, takes place in the vicinity of the printing press, for in a logocracy, political control means control over language. Not coincidentally, the female laborer is a textile worker. ${ }^{20}$ Braun here plays upon the etymological relationship between text and weaving, in order to suggest that the workers are not absolutely separate from the realm of discourse: language belongs to them, and by 
invading the newspaper offices, they simply take back control over the language they are already speaking.

In view of this scene of an uproarious re-appropriation of language against a regime dependent on the newspaper, the fixed phrase can receive its specifically socialist definition. ${ }^{21}$ If the existence of the state presupposes the self-forgetting of the people over which it rules but on which it actually depends, the congealed blocks of words represent the collective's forgetting of its own capacity to formulate itself anew. When everyone reproduces sentences such as "ALLES ZUM WOHL DES MENSCHEN," the collective is denying itself the faculty of speech. The ever-present phraseology of the GDR regime is a particular form of collective self-alienation.

But again, the vision of a workers' uprising only flickers by in one of Karin's dreams, and the story does not end with the reckoning with the officials and the concomitant expansion of the politically controlled repertoire of slogans, dicta, and euphemisms. Instead, Karin remains isolated (although she does reunite with the weakened Frank) and, entirely in accordance with the novella's insistence on the collective or social nature of language, she also remains silent. Despite her principled rejection of an untenable outsider position, her break away from the present collective represented by her family, her peers, and her supervisors - entails a loss of language. She falls out of the regulated traffic of communication and experiences a transformation one could call progressive bestialization. ${ }^{22}$ Again and again, bodily sensations flood her consciousness, in part because the experience of separation from herself and her society strains her mental powers and leaves her palpably exhausted ("Sie war ganz starr vom Denken," 82). But she also rests in her mute bodily existence and takes refuge there from 
the requirements of an existence in and for the state. In a short passage, Braun depicts how Karin eats the food made by Frank's mother, with whom she ends up living, and how she, symptomatically, fills up her mouth: "Die [Pfannkuchen] waren locker und duftend und noch warm im Mund" (95). Away from her place at the newspaper that disseminates state language, Karin ceases to speak and is reduced to, or opts for, a kind of satisfied muteness. Since the project that has pervaded Karin's existence and imbued it with meaning also organized her speech into word clusters and formulae, the withdrawal from “das POLITISCHE LEBEN" brings with it the loss of a voice (93).

In view of Karin's trajectory from the editorial office understood as a node of state rule to the silence of domesticity ${ }^{23}$ and an exclusively bodily existence, Unvollendete Geschichte seems at first to indicate just how effectively language has been monopolized. The protagonist appears to have no capacity of formulation and thought that extends beyond the discourse of the family-workplace-party-state circuit. This suggests a critique of the terrible reach of the oppressive regime, and yet in Braun's case, this critique still agrees with fundamental socialist principles. The text does not gesture to some possibility of an authentically individual idiom breaking through the ossified code of the state, as if the single subject could ever be the source of (linguistic) vivacity and creativity outside of any collaborative interaction with others. The nomenclature of the State is under critique in Braun's novella, but it is not under critique because it is widespread per se. Rather, Karin's silence at the end of the novella indicates that an individual existence is something of a pathological condition, however pleasant it may be. There is no individual uprising, since the very notion of the sharply contoured and independent individual pulverizes the possibility of an effective uprising. Nor can there 
be an individual language, somehow not reliant on repository of common expressions and shared conventions of usage, since such freedom would mean the absence of communication rather than its possible renewal.

\section{IV.}

The young protagonist of Unvollendete Geschichte does not think that the space granted the individual is too constricted or that it must be more protected from the outside intervention of an absolutely alien and predatory force. This would be a liberal notion of the state. Nor does she (or Braun) believe in or hope for a fresh and unique because entirely individual or private idiom, distant from the repertoire of phrases that have accrued to language - this again would be a liberal utopia. The socialist critique of the state, which includes a critique of language, seeks to wrest the regulation of speech from the authorities that claim the privilege to determine it and restrict access to the means of distribution. Yet it does not propose such a re-appropriation of language in the name of the individual, but rather in the name of the collective. From Braun's perspective, the issue is not that Karin has no voice of her own within a system that controls all speech; such an individual voice is never really a feasible project. Instead, the problem with the code given by the state is that language has been monopolized by a part of the people, namely the state bureaucracy or the party elite and the hierarchy beneath them. The problem is in other words that the status of language as truly common has not been fully realized. The ubiquitous slogans of the entrenched regime should certainly be replaced, but only by the equally ubiquitous slogans of the genuinely empowered working class flooding the newspaper bureaus. 
Returning to the issue of Volker Braun's disappearing socialism, we can now see that the established approach to Unvollendete Geschichte fails to notice how Braun's image of the dismissed and silenced individual does not amount to an endorsement of that individual as an individual, but should rather be read as a call for a truly socialist collective. The novella does depict how an individual is powerless against the state, but Braun's point is that the person somehow on the outside of the collective is synonymous with powerlessness to begin with. Either there is genuinely collective action, or there is no effective action at all. Nor does the frequent inclusion of state phraseology into the body of the text constitute an uncomplicated critique of the hardened phrase, as if another register were immediately available. On the contrary, these pervasive quotations may testify to the fact that there is no other language than the one spoken by Karin as well as by everyone else. Braun himself cannot write a book without recourse to them. What appreciative reviewers call the author's ongoing satirical exposure of a reified language could just as well be seen as his admission of his own inability to transcend this language completely.

Braun's own insight into the limitations on language and imagination determined by the current social formation goes some way towards explaining how his own commitments have become invisible to readers in the (victorious) West. The system he lived in, with its lexicon of key words and ideological tradition, has vanished, leaving an age of relative liberal hegemony. In this situation, the premises of his socialist resistance to the state have also faded from view. Braun's brand of radicalized collectivism becomes difficult to understand without a regime that constantly invoked but simultaneously sought to occupy collectivism. With an ease and swiftness that is quite overwhelming to 
Braun, his suddenly alien line of thought has been assimilated into the categorizations

and plot lines of the dominant ideology, and his critique of the state seems quite like a

quasi-liberal defense of the individual. Ironically, the conceptual overlaps between

socialism and liberalism (both ideologies have a notion of state structure etc.) have served

to preclude rather than facilitate an understanding of his work. In the case of Braun, a

false obviousness rather than a recognizable obscurity calls for a re-interpretation of his

literary work. Braun's message would perhaps have resonated in a different way with a

readership in the East, familiar with the mode of thought to which he was and still is

faithful. But there, of course, his work was censored by the regime he set out to critique.

\footnotetext{
${ }^{1}$ In his recent survey of leftwing and Marxist thought and politics, the social theorist Göran Therborn comes to a similar conclusion: "The socialist horizon, bright red just three decades ago, has vanished"

${ }^{2}$ For a recent discussion of the fate of communist monuments, see Hana Pichova, "The Lineup for Meat: The Stalin Statue in Prague," PMLA 123.3 (May 2008) 614-30.

${ }^{3}$ The Economist summarized recent findings about student ignorance of GDR history in Germany: "Every

German schoolchild learns to revile Hitler, but what about Erich Honecker, boss of communist East Germany? He was not a dictator, or so most teenagers from eastern Germany seem to think." The Economist, October 23, 2008. But however common, the trivializing sentiment of "Ostalgie" is hardly a strong political affect such as anger or outrage. For this reason, it is unlikely to inspire some broad attempt to return to socialism. Nostalgia is a longing for a past that is unredeemable, or, as Jonathan Bach has proposed in the context of the changing image of the GDR, "a longing for a mode of longing that is no longer possible" (547). What has been irrevocably lost is not a society but rather the fantasies that were once possible. Jonathan Bach, “"The Taste Remains': Consumption, (N)ostalgia and the Production of East Germany," Public Culture 14.3 (2002) 545-56.

${ }^{4}$ Fredric Jameson speaks of a socialist "Second World," a bloc that belonged neither to the capitalist West, nor to the "Third World" of underdeveloped countries. Fredric Jameson, The Seeds of Time (New York: Columbia UP, 1996) xvi.

${ }^{5}$ By stressing how centrally organized economic planning cannot make use of the dispersed knowledge of multiple, situated individuals, the economist Friedrich von Hayek famously found a way to attack socialism for the twin evils of inefficiency and coercion. According to Hayek, free markets allow individuals to act upon the local information and unique (if incomplete) knowledge they possess. Socialist central planners, who are just as knowledgeable or ignorant as anyone else, could not possibly absorb and process this socially fragmented knowledge to decide on the proper course of the entire economy. Their inherently hubristic designs, guided by some narrow conception of what is needed or good, always blocked individuals from using their knowledge - it both constrained them and reduced their contribution to the economy. For a recent reconstruction of Hayek's influential argument and its place in intellectual history, see Erik Angner, Hayek and Natural Law (London: Routledge, 2007).

${ }^{6}$ In an article on socialism as an alternate modernity, Benjamin Robinson cites the near-consensual notion that socialist East Germany (and by implication the entire Eastern Bloc) "failed on certain persuasive scales of modernity: it did not create a state based on popular legitimation, it did not accumulate the material
} 
wealth to challenge the liberal industrial model of development in the West, and it did not set new standards for the quality of life" (705). Robinson departs from this judgment by claiming that socialism's failure should be seen less in its underperformance according to a set of criteria that arguably represent a universal model of modernity than in its inability to "establish persuasive criteria for its own effective and legitimate self-description" (723). Benjamin Robinson, "Socialism's Other Modernity: Quality, Quantity and the Measure of the Human," Modernism/modernity 10.4 (2003) 705-28.

${ }^{7}$ Braun's novella appeared in the East German literary magazine Sinn und Form in 1975, but after having slipped through censorship at first, it was intercepted and did not come out as a book in the GDR. In 1977, Suhrkamp published it in West Germany. Subsequent references will be made parenthetically to Volker Braun, Unvollendete Geschichte (Frankfurt am Main: Suhrkamp, 1977).

${ }^{8}$ This schematic characterization of a conflict between "staatlichen Machtanspruch und individuelles Glück" is sufficiently established to appear in literary encyclopedias. The quotation is drawn from Kindlers Neues Literaturlexikon. Ed. Walter Jens, vol. 3 (München: Kindler, 1988) 64.

${ }^{9}$ The focus on language in Unvollendete Geschichte is not a feature of a single literary work, but can be understood as a constitutive feature of the society that Braun depicts. In a recent work, the cultural theorist Boris Groys has suggested that communism strives to implement a "Versprachlichung" of the entire social order. See Boris Groys Das kommunistische Postskriptum (Frankfurt am Main: Suhrkamp, 2007) 9. Communists attempt to subordinate the economy, and indeed all areas of collective life, under political rule. Since political rule depends on the use of language in the form of declarations, arguments, prohibitions etc., this project amounts to a "linguistic turn" on an unprecedented scale.

${ }^{10}$ Volker Braun, Die unvollendete Geschichte und ihr Ende (Frankfurt am Main: Suhrkamp, 1998) 106-7.

${ }^{11}$ Braun himself has noted that his work has become difficult to understand because the conditions under which he produced it have been transformed. And this judgment has also entered the German feuilletons. The critic Mark Siemons, for instance, writes about Braun's uneasy existence as an author suspended between East and West: "Der alte Rahmen des Lebens und Denkens ist ihm [Braun] entfallen, einen neuen will er nicht akzeptieren. 'Und unverständlich wird man ganzer Text,' hatte er gleich nach der Wende geschrieben. Siemons, "Drei Welten," Frankfurter Allgemeiner Zeitung, March 5, 1997. In this paper, however, I pursue a very different line of argument. The problem is not that Braun's work has become strange or obviously unintelligible today, as if written in a lost language, but rather that his text remains eminently readable. What needs to be addressed is the work's quick assimilation by liberal culture, not its palpable resistance to it.

${ }^{12}$ Ute Brandes and Ann Clark Fenn, "Werther's Children: The Experience of the Second Generation in Ulrich Plenzdorf's Die Neuen Leiden des jungen W. and Volker Braun's 'Unvollendete Geschichte'," The German Quarterly 56.4 (Nov 1983) 608-23; 611.

${ }^{13}$ I draw this formulation from Wolfgang Emmerich, Kleine Literaturgeschichte der DDR, 1945-1988 (Frankfurt am Main: Luchterhand, 1989) 296.

${ }^{14}$ The historian Mary Fulbrook attributes the relative political stability of the GDR over several decades to mass conformity rather than mass support and further claims that "conformity is more likely to be achieved where the system of domination operates smoothly." Broad challenges to the system, she argues, only occur when organization (in contradistinction to ideology) begins to break down and "carriers of the system" are internally divided. Braun's novella may describe an unjust or morally and politically inflexible system but not a non-functioning one. Karin is up against a rather smoothly operating system of domination. Mary Fulbrook, Anatomy of a Dictatorship: Inside the GDR 1949-1989 (Oxford: Oxford UP, 1995) 274.

${ }^{15}$ George Büchner, Werke und Briefe. Münchner Ausgabe. Ed. Karl Pönbacher et al. (Munich: Carl Hanser, 1988) 43. The quotation in the original manifesto reads: "Was ist denn das für gewaltiges Ding: der Staat?" ${ }^{16}$ Büchner emphatically states "Der Staat sind also alle." Büchner, Werke und Briefe 43.

${ }^{17}$ This idea in Unvollendete Geschichte is in line with socialist thought, and in a rough fashion agrees with a Marxian analysis of the State power. According to the philosopher Etienne Balibar, Marx believed that the state emerges as a power through an inversion of the relationship between individuality and community: the community of individuals is dissolved into fragments and their "social relation" is projected "onto an external 'thing'." Etienne Balibar, The Philosophy of Marx, trans. Chris Turner (London: Verso, 2007) 76. As the political philosopher Pierre Rosanvallon has pointed out, Marx was in a sense deeply engaged in the "rehabilitation of civil society against the state." Pierre Rosanvallon, Democracy Past and Future, ed. 
Samuel Moyn (New York: Columbia UP, 2006) 162. In a similar vein, the Foucault-inspired scholar Colin Gordon asserts that Marx believed the state to be nothing but an "excrescence" of civil society (30). Colin Gordon, "Governmental Rationality," The Foucault Effect: Studies in Governmentality. Ed. Graham Burchell, Colin Gordon, Peter Miller (London: Harvester, 1991) 1-51.

${ }^{18}$ Writing on Roland Barthes, Susan Sontag states that a bid "to have the final word is inherent in all powerful phrase-making." Roland Barthes: Selected Writings, ed. Susan Sontag (London: Fontana, 1983) xii.

${ }^{19}$ In Marc Silberman's judgment, the East German leadership was positively paranoid about the power of the word: "Revisionists, dissidents, and renegades were not mere class enemies but betrayers who interpreted the 'sacred' words and texts differently and therefore threatened the maintenance of power." This leads him to the claim that socialism has a "logocratic" tendency. Marc Silberman, foreword to What Remains? East German Culture and the Postwar Public, ed. Marc Silberman, Harry \& Helen Grey Humanities Program Series, vol. 2 (Washington D.C.: AICGS, 1997) 10-11.

${ }^{20}$ In an essay on the novella that depends mostly on paraphrase, Theo Rauch suggests that the female textile worker gives Karin's dream a mythical dimension: "Die Tätigkeit des Webens verweist auf das Vorbild der Parzen, und Volker Braun gibt der Weberin damit eine mythische Dimension" (156). However, he does not develop this idea further, nor does he integrate it into an overarching argument. Theo Rauch, "Volker Braun: Unvollendete Geschichte," Erzählen, Erinnern: Deutsche Prosa der Gegenwart. Ed. Herbert Kaiser and Gerhard Köpf (Frankfurt am Main: Moritz Diesterweg, 1992) 149-71.

${ }^{21}$ The dependence of communist parties on newspapers is not a fact observed from outside of the movement, but rather one of its explicitly formulated and indeed central ideas. Lenin himself writes: "A newspaper is not only a collective propagandist and a collective agitator, but also a collective organizer. V. I. Lenin, What Is to Be Done? trans. Joe Feinberg and George Hanna (London: Penguin, 1988) 223. As she starts working at the newspaper, Karin's thoughts are guided by precisely this Leninist understanding of the instrumental role of the party daily. Braun writes: "Den Arbeitern, die ja, wie Genosse Lenin sagte, ihr Bewußtsein nicht selber bekommen können, denen muß man es bringen. Man muß es eben in sie hineintragen. Die Zeitung ist dazu am besten geeignet, man braucht sie nur zu lesen. Die Mutter arbeitete nachts in der Lokalredaktion. Die Zeitung ist der kollektive Agitator. Und der Organisator, wenn sie die Arbeiter zum Handeln bringen" (22).

${ }^{22}$ Braun writes: "Nur manchmal, wenn sie ganz ruhig war und zu sich kam, drehte sich alles heraus an ihr, sie war das Fleisch und die Haut, und das Haar, und empfand sich mit allen Fasern, lag so da" (33).

${ }^{23}$ Recent years have seen a broad discussion of everyday life in the GDR, which typically includes an interest in domesticity under socialism. This trend has now made it into the official world of important German museums such as the Deutsches Historisches Museum in Berlin. See the catalogue Parteidiktatur und Alltag in der DDR. Ed. Regine Falkenberg (Berlin: Deutsches Historisches Museum, 2007). Some researchers have suggested that the domestic space offered East German citizens a much-needed shelter from a controlled public life: "East Germans were just as likely and just as entitled to be house-proud as people from any culture, but it should not be forgotten that the space of the domestic was the only place where any discontented resident of the GDR could imagine an internal emigration from himself or herself." Charity Scribner, Requiem for Communism (Cambridge MA: MIT P, 2003) 34. Braun clearly observes this path towards a private life and does not diminish its pleasures, but he views the retreat from "political life" as a terrible loss. 